\title{
Experimental Physiology
}

Chairman of the Editorial Board: Professor C. Kidd, Marischal College, University of Aberdeen

Experimental Physiology is published six times a year allowing the swift appearance of important information. The editorial policy is to publish the fruits of research in all areas of physiology with particular emphasis on whole animal and systems physiology. Papers on those facets of cellular and molecular biology especially relevant to the understanding of integrative mechanisms in animals and man are also welcomed.

Fast publication

An important aspect of Experimental Physiology is its quick handling of full length papers coupled with the high standard of refereeing and the high quality of the finished articles and offprints. A special feature is the Rapid Communications Section which allows the publication of short papers within 2.5 months of specified deadlines.

Subscription: $£ 43 / 80$ for individuals, $£ 102$ for UK subscribers, $£ 107 / \$ 205$ elsewhere, delivery by airmail $£ 32$ per year extra. ISSN 0958-0670.

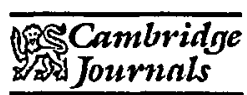

\section{Cambridge University Press}

The Edinburgh Building, Cambridge CB2 2RU

40 West 20th Street, New York, NY 10011-4211, USA

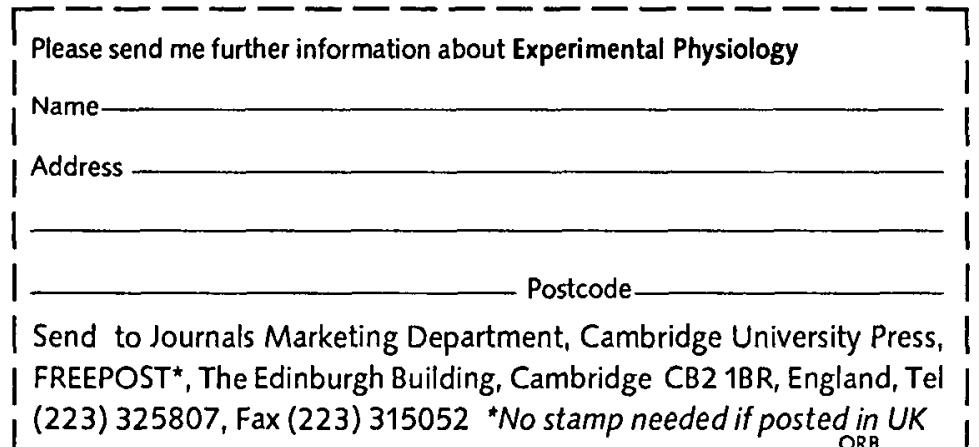


NEW IN

1992...

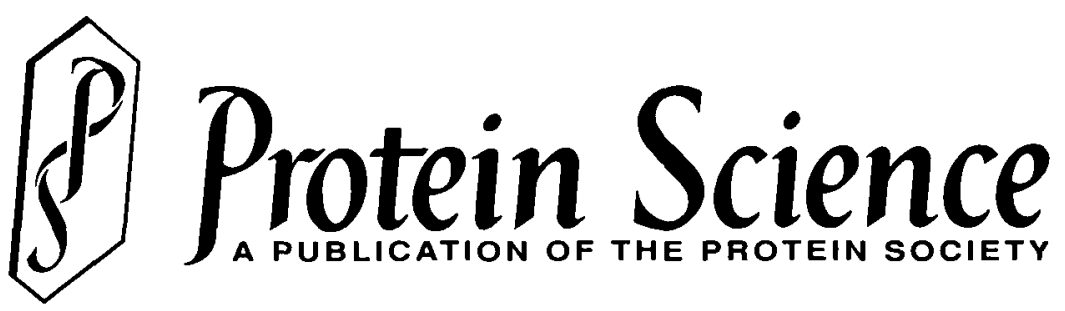

Editor:

Hans Neurath

\section{Associate}

\section{Editors:}

Rolph A. Brodshow Tony E. Hugli

Louise N. Johnson

Rachel E. Klevit

Christopher T. Walsh

\section{Editorial}

Consultant:

David S. Eisenberg

\section{Graphics}

Consultant:

Jane S. Richardson

\section{Editorial}

Advisory Boord:

The edilors will be

assisted by an interna.

tional board of over

50 distinguished

prolein scientists.

\section{CAU FOR PAPERS}

All interested scientists in protein research are encouraged to submit their best work to Protein Science, the new international forum for original reports on proteins. Members of The Protein Society throughout the world will receive the Journal as part of their membership dues. The wide scope of the journal will include the:

- structure, function and biochemical significance of proteins

- role of proteins in molecular and cell biology

- role of proteins in genetics and evolution

- regulation and mechanism of action of proteins

The entire spectrum of experimental methodologies will be covered, including such calegories as

- isolation, characterization, chromalography

- chemistry, synthesis of peptides and proteins

- crystallography

- NMR spectroscopy

- protein sequencing, modification, mass spectroscopy

- cDNA, doning mutagenesis

- computational analysis

- electronic dala deposition and processing

Detailed Instructions for authors available from:

Hans Neurath, Editorin-Chief

PROTEIN SCIENCE

University of Washington, $\$ 570$

Seatle. WA 98195 USA

FAX: 206/685-2674

EMAll: prosci@u.washington.edu

Protein Science will be published for The Protein Society by Cambridge University Press 


\section{INSTRUCTIONS TO AUTHORS}

I. Quarterly Reviews of Biophysics is the official journal of the International Union for Pure and Applied Biophysics. As such, its primary aim is to provide a forum for general and specialized communication between biophysicists working in different areas. This will normally be achieved by inviting authors who have made significant contributions to give a critical and readable account of recent progress in their special fields. Shorter and even controversial articles discussing topics of particular current interest will also be published. Suggestions for reviews can be made to the editors.

2. The style of presentation must be concise, with only key references.

3. Three copies of manuscripts are required. They should be typed in double spacing throughout, including the list of references, with a margin of $4 \mathrm{~cm}$ all round. The position of tables and illustrations should be indicated in the text. Tables and legends for illustrations should be typed on separate pages. A table of contents should be provided for printing at the head of the article. Chapter and section headings and the table of contents should conform to the style in any issue from volume 19 onwards.

4. In the text, the references should be to authors and year. When a paper cited has three or more authors the style Smith et al. (1973) should be used on all occasions. At the end of the paper, references should be listed alphabetically, with the full title of each paper, and the first and last pages. Abbreviations of journal titles should follow the World List of Scientific Periodicals. Authors should follow the example below for layout and punctuation:

Bernal, J. D. (1967). Origins of Life. London: Weidenfeld and Nicolson. Eigen, M. (1968). New looks and outlooks on physical enzymology. Q. Rev. Biophys. r, 3-33. Swenberg, C. E. \& Geacintov, N. E. (1973). Exciton interactions in organic solids. In Organic Molecular Photophysics, vol. I (ed. J. B. Birks), pp. 489-564. London: Wiley.

5. Drawings and photographs should be of the highest possible quality. The maximum size should be A4. Explanations should as far as possible be placed in the legends. Lettering for drawings and photographs should either be on a duplicate print or on an accurately registered overlay.

6. The author will receive only one set of page proofs for correction. Fifty reprints of each review will be provided free of charge. In the case of multiple authorship these proofs and offprints will be sent to the first-named author only. One hundred additional copies may be purchased if ordered at the time proofs are returned.

\section{COPYING}

This journal is registered with the Copyright Clearance Center, 27 Congress Street, Salem, Mass. or970. Organizations in the USA who are also registered with C.C.C. may therefore copy material (beyond the limits permitted by sections 107 and 108 of US (C) law) subject to payment to C.C.C. of the per-copy fee of $\$ 05.00$. This consent does not extend to multiple copying for promotional or commercial purposes. Code $0033-5835 / 91 \$ 5.00+.00$.

ISI Tear Sheet Service, 350 I Market Street, Philadelphia, Pennsylvania 19104, USA, is authorized to supply single copies of separate articles for private use only.

For all other use, permission must be sought from Cambridge or the American Branch of Cambridge University Press. 


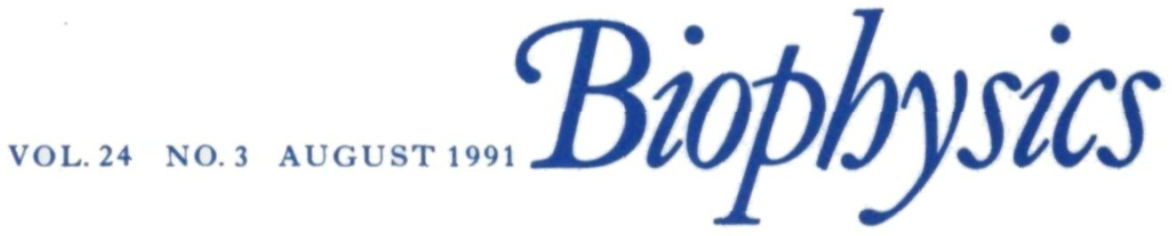

\section{QUARTERLY REVIEWS OF}

\section{CONTENTS}

J. C. SMITH

Protein dynamics: comparison of simulations with inelastic neuron scattering experiments

M. BLOOM, E. EVANS AND O. G. MOURITSEN

Physical properties of the fluid lipid-bilayer component of cell membranes: a perspective

\section{FORTHCOMING REVIEWS}

\section{C. LAWRENCE}

The application of the molecular replacement method to the de novo determination of protein structure

D. OESTERHELT, C. BRÄUCHLE AND N. HAMPP

Bacteriorhodopsin: A biological material for information processing

G. VARANI AND I. TINOCO, JR.

RNA structure and NMR spectroscopy

(C) Cambridge University Press 199I

\section{CAMBRIDGE UNIVERSITY PRESS}

The Pitt Building, Trumpington Street, Cambridge CB2 IRP 40 West 2oth Street, New York, NY Ioor I-42II, USA 1o Stamford Road, Oakleigh, Victoria $3 \times 66$, Australia 